\title{
ISLAMIZING THE MANAGEMENT OF HUMAN RESOURCES IN SCHOOLS: THE IMPERATIVE FOR MUSLIM PROPRIETORS OF SCHOOLS
}

\section{Rafiu Ibrahim Adebayo}

Department of Religions. University of Ilorin, P.M.B. 1515. Ilorin. Nigeria.

Email: adrafhope@yahoo.com

\begin{abstract}
Khulasah
Pertumbuhan pesat institusi pengajian yang ditubuhkan oleh pertubuhan-pertubuhan dan individu Islam boleh dikatakan sebagai satu perkembangan baik walaupun mereka masih belum bersaing secara kuantiti dengan institusi pengajian yang ditubuhkan oleh pertubuhan-pertubuhan dan individu Kristian. Walau bagaimanapun, dapat diperhatikan bahawa kebanyakan institusi pengajian yang mendakwa sebagai Islamik ini hanyalah berdasarkan nama-nama yang diberikan sahaja kerana didapati hampir tidak ada perbezaan antara bentuk operasinya dengan corak operasi institusi pengajian sekular. Artikel ini bertujuan untuk mengenal pasti dan membincangkan beberapa prinsip yang akan menjadikan sesebuah institusi pengajian Islam itu benar-benar Islam dari aspek operasinya. Oleh yang demikian, pemilikpemilik institusi tersebut perlu memainkan peranan dan mengambil tanggungjawab dalam tugas merancang, mengurus, memimpin, menyelaras, mengarah, menyelia, mengawal, menilai dan melaporkan peranan institusi masing-masing untuk memastikan institusi tersebut sebagai institusi pengajian Islam yang sebenar. Tugas-tugas ini hanya boleh dicapai apabila pengurusan sumber manusia di institusi tersebut diurus dengan betul secara Islam.
\end{abstract}

Kata Kunci: Pengurusan, sumber manusia, Islamisasi, institusi, pemilik 


\begin{abstract}
The proliferation of institutions of learning established by Muslim organizations and individuals could be said to be a welcome development though they are yet to compete numerically with those established by Christian organizations and individuals. However, it is observed that many of these institutions are only recognized to be Islamic by their names as there is hardly any difference between their operation and the secular ones. This paper identifies and discusses some principles which will make Muslim schools really Islamic in nature and operation. Proprietors of these schools therefore need to be up and doing in the task of planning, organizing, leading, coordinating, directing, supervising, controlling, evaluating and reporting roles for their schools to be real Muslim schools. These tasks can only be accomplished when human resources in schools are properly managed in the Islamic manner.
\end{abstract}

Keywords: Management, human resources, Islamization, schools, proprietors

\title{
Introduction
}

Right from the inception of man on earth, seeking of knowledge has being a major task of human endeavour. This explains why Allah Himself taught Adam, the first man, the nature of all things. With this, mankind became elevated above the angels. ${ }^{1}$ Also, there is wisdom in the first revelation to Prophet Muhammad (S.A.W) where the Prophet who was to preach Tawhid was firstly asked to "read in the name of your Lord." highly symbolic in the Islamic education philosophy. In the first instance, the Prophet was not literate; he could neither read nor write, yet he was asked to read. By implication, reading does not mean the art of reading the

\footnotetext{
${ }^{1}$ See Qur'an 2:30-34.

${ }^{2}$ Qur'an 96:1-5.
} 
'book of revelation' alone, but also the reading of the 'book of creation.' Apart from this, knowledge is the basis of faith, as seen in the following Qur'anic verses:

Behold! In the creation of the heavens and the earth, and the alternation of night and Day, there are indeed signs for men of understanding. Men who remember Allah standing, sitting and lying down on their sides, and contemplate the wonders of creation in the heavens and the earth, (with the saying): "Our Lord not for naught, have you created all this! Glory to You! Give us salvation from the chastisement of the fire. (Q3: 191-192).

It needs to be observed that the ultimate aim of education in Islam is to produce a complete personality who is righteous in all its ramifications. Therefore, knowledge, faith and good deed are the foundation of achieving this. No wonder then that education in Islam is aimed at producing a "balanced growth of the total personality of man through the training of man's spirit, intellect, the rational self, feelings and bodily senses." 3 The First World Conference on Islamic Education further gives an insight to the aim of education in Islam thus:

Education should therefore cater for the growth of man in all its aspects: spiritual, both individually and collectively, and motivate all these aspects towards goodness and the attainment of perfection. The ultimate aim of Muslim education lies in the realization of complete submission to Allah on the level of the individual, the community and humanity at large. ${ }^{4}$

${ }^{3}$ S.S. Hussein \& S.A. Ashraf, Crisis in Muslim Education (Jeddah: Hodder and Stoughton and King Abdulaziz University, 1979), 44.

${ }^{4}$ Ibid. 
The aim of education as designed by the First World Conference on Islamic Education as indicated above, should serve as a guiding principle for Muslim educators, writers, administrators and those in other professional sectors. This implies that Muslim school administrators have hard nut to crack for them to be able to administer their schools in such a way that they produce a balanced personality, pleasing to God and to fellow humans. In other words, Muslim schools are supposed to be pathway to achieving good in this world and the hereafter.

It should be mentioned that an Islamic school is answerable to Allah, and so, the school needs to formulate a mission statement that reflects Islamic ethos, while the structured and unstructured curriculum are geared towards providing an environment for Islamic attitudes and values. In addition to this, an Islamic school is answerable to the parents, pupils, governments and the society at large. As such, all hands must be on deck to ensure that Islamic schools are able to face these challenges through effective management. Thus, for a serious Islamization of knowledge exercise to take place in a Muslim school, the totality of the school curriculum is expected to be given Islamic touch.

By Islamizing the curriculum, we mean enriching and vitalizing the programmes of studies, activities and guidance in a school with Islamic teachings and principles. The Islamization of the curriculum takes the form of practicing intellectual and other planned and unplanned activities in the school based on the Islamic concept of the universe, life and man, which a child is exposed to under the control of the school. ${ }^{5}$ In the same vein, Islamizing the management of the school involves managing the human and non-human resources in the

${ }^{5}$ R.I. Adebayo, "Islamization of the Curriculum: An Agenda for the Private Islamic Nursery Schools in Nigeria," Muslim Education Quarterly, vol. 22, no. 3, (2005), 10. 
school system in the light of Islamic principles. It is, therefore, the aim of this paper to consider some Islamic ethical values relevant to managing human resources for the adoption of Muslim school managers, so as to make the dream of giving both Islamic and the Western education to the students in these schools a reality.

\section{The Concept of Islamization of Knowledge}

The belief that knowledge though emanated from Allah, is usually a product of human experience which has been processed and exposed to human whims and caprices through environmental and other influences, made Muslim scholars to realize that unless knowledge was Islamized, Muslims would be made to forget their religious worldview and so would be promoting alien culture at the detriment of theirs.

Though there had been numerous calls for reform of Muslim education by some Muslim reformers like Sayyid Aḥmad Khan, Jamal ad-Dīn al-Afghāni, Muhammad 'Abduh, Rashīd Ridhā, Maulana Abu al-`A'lā Mawdūdī, Hasān al-Banna and Sayyid Qutb among others, the 1977 World Conference on Muslim Education held in Makkah served as an eye opener for the Muslims to realize the need for Islamization of knowledge as a means of resuscitating and revitalizing Muslim education. ${ }^{6}$

At the conference, the idea of Islamization of knowledge was mooted and it was agreed upon that a means of saving the Muslim world from educational peril was adoption of the Islamization of knowledge programme. Subsequent conferences in Islamabad (1980), Dhaka (1981), Jakarta (1982), Cairo (1987), Cape Town (1996) and Malaysia (2009) were organized to chart a course for the Islamization programme in the areas of

${ }^{6}$ R.I. Adebayo, Islamization of Knowledge: Global Developments, Individual Efforts \& Institutional Contributions (Kano: IIIT Nigeria Office, 2008), 14-49. 
textbook development, teaching methodology as well as disseminating the Islamized knowledge to the world. ${ }^{7}$

Islamization of knowledge is conceptualized by Sulaiman as an "attempt through which aspects of the body and purpose of knowledge and of the process and methodologies of discovering, validating, imparting and applying it, which oppose Islam, are made subservient to the Islamic worldview." ${ }^{8}$ To achieve this, some institutions were put in place. These included the International Institute of Islamic Thought, the International Institute of Islamic Science and Technology, the International Board of Educational Research and Resources and the Islamic Academy among others. Also, some universities were established for the purpose of Islamizing knowledge. Such included the International Islamic universities in Malaysia, Uganda and Islamabad and the Graduate School of Islamic and Social Sciences of the International Institute of Islamic Thought (IIIT) in the United States.

\section{Who are the School Managers?}

The term 'Human Resource Management', addressed under different nomenclatures like 'Manpower Management', 'Personnel Administration' or 'Personnel Management', can be defined as the management of the bulk of labour available for any particular kind of work. ${ }^{9}$ Gbosi looks at human resources from economic point of view when he says: "it is the bulk of human beings with the relevant skills, energies, talents, knowledge and attitudes that can be committed towards the production of

\footnotetext{
${ }^{7}$ Adebayo, Islamization of Knowledge, 50-51.

${ }^{8}$ S. Sulaiman, Islamization of Knowledge: Background, Models and the Way Forward (Kano, IIIT Nigeria Office, 2000), 19.

${ }^{9}$ C.O. Agabi \& J.I. Ogah, "Education and Human Resource Planning in Nigeria: The Case of National Manpower Board (NMB)," International Journal of Scientific Research in Education, vol. 3, no. 3 (2010), 152-165.
} 
goods and services." ${ }^{10}$ It can therefore be defined from the Islamic perspective, as the functions of dealing with human aspects of an organization or management process concerning people at work in an organization in the light of the principles of Islamic ethical values so that the employees get maximum satisfaction without jeopardizing the benefits of the employers.

The saying of the Prophet that "all of you are shepherds and all of you will be asked concerning the flock" (Bukhāri), gives a clear picture of who a manager is. By implication, everybody is a manager in his capacity, at his or her area of assignment in a system. In this wise, every human personnel in a school set-up is a manager, with the addition that someone is assigned the duty of being an overseer over the other. Also the level at which individual in the system operates differs just like a Local Government Chairman operates in his local territory and a State Governor operates at state level; but all are working for the development of the country at large.

In essence, the managers of an ideal school include the school proprietor or coordinator in the case of mission schools; the head-teacher, assistant head-teacher, teachers and even parents. Others include such local, state, federal and international statutory bodies which have certain influence on the education set-up. However, for schools to be effectively managed and to avoid conflict of responsibility, there should be an organization structure each assigned duties and responsibilities with commensurate authority. Normally, a private primary school organogram consists of the proprietor, the headteacher, the assistant head-teacher, the teaching staff, the non-teaching staff, the school prefects and the students.

10 A.N. Gbosi, Economic of Human Resources Development (Choba: Emiham Printing and Publishing Co., 2003), 3. 
The school hierarchical and administrative set-up confirms the Qur'anic statement that: "We raise some of them above others in ranks so that some may command work from others..." (Q 43:32). The relevance of this verse to modern management is that it showcases the recognition of division of responsibilities subject to individual capabilities.

There is wisdom in the Prophet mentioning the word 'shepherd'. Just as a shepherd has the role of grazing his sheep, looking after them and ensuring their safety, the school manager also has the responsibility of ensuring the well-being, health, safety, and development of those under him. Some lessons can be learnt by a school administrator from a shepherd. A shepherd takes care of his flock against the threat of wolf and other external attacks by scanning the environment to ensure freedom from dangerous animals. He is vigilant to see that none of the flock goes astray.

In the same vein, a school administrator in an Islamic school sees that he takes great care of those under him, so that none of them is derailed from the laid down rules and regulations of the school. Just as the shepherd will continue to be in the bush with his flock bearing all types of weather and uncomfortable environment, a school manager is also expected to display sense of hardworking, ever available in the school and sacrifice his leisure time for the benefit of those he manages.

\section{Some Islamic Management Principles Relevant to the Muslim School Managers}

It is generally believed that Islam is a comprehensive religion that touches every aspect of human life. As such, every human action is considered an act of 'ibādah. This implies that establishment of schools by Muslim individuals and corporate bodies should be seen far beyond a business venture which is run for the purpose of earning livelihood alone. As such, the Islamic mechanism 
of management should be employed in the day-to-day running of the institution so as to attract both terrestrial and celestial benefits. The expectation of celestial benefit from establishment of schools is indeed a line of demarcation between conventional non-Islamic schools and conventional Islamic schools.

Islamic Management is an emerging discipline which emanates from the revealed and other Islamic sources which lead to managerial applications that are compatible with the Islamic beliefs and practices. From these, some principles are framed by scholars in the field of management, which to us, are equally relevant to Islamic school administrators or managers. These principles are discussed below.

\section{a. The Principle of Khiläfah and Amānah (Vicegerency and Trusteeship)}

By virtue of the fact that man is a vicegerent of Allah on the earth, he sees himself as carrying out all his activities on earth on the dictate of Allah who gave him this opportunity. As a khalifah, whatever he owns in terms of intellect, knowledge, wealth and power, is an amānah entrusted to him by his Creator and so will render an account of how he has taken care of such to Allah.

In the same vein, a school administrator in whatever capacity he finds himself is expected to see himself as a vicegerent of the senior official. A teacher in the class for instance is a representative of the principal or head teacher, and the principal as well, is the representative of the school proprietor. Also, the children in their custody are amānah and so should do everything possible to take adequate care of them, as at the end of the day, they are going to be accountable for how far they have discharged the responsibility of taking care of their soul, body and intellect. Taking care of their soul entails the nature of spiritual education they expose them to, while taking care of their body implies the safety measure being put in place 
in the school. The overall subjects in the school system constitute the nature of intellectual development the students attain at the end of their education in the school.

\section{b. The Principle of Institutional and Personal Loyalty}

Islamic management is based on the non-exploitative relationship between labour and capital representing employees and employers respectively. It is based on the principle of institutional and personal loyalty. In this wise, personal loyalty should not jeopardize that of institutional loyalty. By institutional loyalty, an employee obeys the rules and regulations laid down for the smooth-running of the institution. He is expected to do his job efficiently and honestly.

It should be noted that Islamic management is both objective and personality oriented, just as management principle stresses on the development of both the institution as well as individual. The pursuance of individual objective is permissible as long as such does not come into conflict with the collective objectives of the community as a whole. As such, a teacher in a school system is not expected to embark on any other programme that will jeopardize his effective performance in his place of work. An instance where a teacher engages in furtherance of his studies could be seen as a welcome development, but still, he has to do that with the knowledge of the school management, so that adequate alternative arrangement could be made by the school, for the students not to be suffering unnecessarily.

In the same vein, school activities should not jeopardize personal development of the teachers. Where this occurs, such a teacher must be adequately compensated. There are instances where schools engage teachers beyond the normal school hours. In such an instance, adequate compensation should be given to the teachers involved, or else the feeling of injustice and 
deprivation on the part of the teacher will set in, and this can affect the school negatively.

\section{c. The Principle of Work and Reward}

It is a law of existence that any work done should be rewarded accordingly. It therefore becomes the duty of the school management to ensure that employees are fully paid in due time. A famous Hadith of the Prophet (SAW) states that a worker's wage must be paid before his sweat dries. This clearly demonstrates that the employee is an object of care and concern and as such, speedy payment of wages conveys this message. It needs to be mentioned as well that the monthly take-home of the employees in a Muslim school should commensurate with the school fees paid by the students. Where the school takes much but pays less to the employees, it amounts to injustice and fraudulent act of taking too much and giving too little. The following Qur'anic verses confirm this:

Woe to those that deal in fraud. Those who, when they have to receive by measure from men, exact full measure. But when they have to give by measure or weight to men, give less than due. Do they not think that they will be raised up? (Q.83:1-4).

The Qur'an further narrates the story of the people of Prophet Shua'ib who were engrossed in the habit of giving less to get much by means of exploiting people through giving false measure. Shua'ib was thus sent to them to warn them to "give full measure, and do not be of those who give less (than what is due). And weigh with the straight balance, and do not diminish people's goods nor do evil on the earth, making mischief" (Q26:181-183).

\section{d. The Principle of Shūra (Consultation)}

The scheme of the Shari' 'ah encourages that management should try to create a working environment, which generates co-operative forces and encourages consultation 
in the process of decision making process. The fact that Ijma $^{c}$ serves as a source of Islamic law confirms this assertion. Due consultation is therefore seen as an effective means of carrying along the employees in the decision-making process of the school organization. This also allows for proprietor-staff relationship which consequently moulds the management and administrative behaviour and as well leads to development of sense of collectiveness, cooperation, unity and togetherness, which are ingredients to achieving organizational goals.

\section{e. The Principle of 'Adl (Justice and Fairness)}

The principle of justice is premised on the Qur'anic verse which reads:

Allah commands justice, benevolence and liberality to kith and kin, and He forbids all shameful deeds and injustice and transgression. He instructs you that you may receive admonition (Q.16: 90).

Justice implies paying what is due to others and fair treatment with all parties concerned. ${ }^{11}$ A human resource manager is expected to practice justice and fairness in his dealings with the employees as well as the enterprise in both interpersonal and inter-group interests. Justice in this sense, is more than the Golden Rule 'do as you would be done by', it demands that one should give in full what is due from him whether he expects or wishes to receive full consideration from the other side or not. As in case of work, appropriate reward should be a compensation for productive work. Justice also demands that a school proprietor should not recruit unqualified teachers to teach in his school, in view of the fact that parents who bring their wards to his school expect the best offer in terms of education and moral development of their wards.

11 M.A. al-Buraey, Management and Administration in Islam (n.p, 1990), 83. 


\section{The Managerial Challenges of a Muslim School Administrator}

\section{a. Planning}

Shehu Adam has a catalogue of definitions of the term manpower planning. He cited Walker and Beach who define it as "a process of analyzing an organization's human resources' needs under changing conditions, and developing the activities necessary to satisfy these needs" and "a process for determining and assuring that the organization will have an adequate number of qualified persons, available at the proper times, performing jobs which meet the needs of the enterprises and which provide satisfaction for the individuals involved" respectively. ${ }^{12}$ It is also a process of using available resources more economically and efficiently in order to achieve organizational goals. ${ }^{13}$

Before starting a school, the proprietor needs to consider the following questions as contained in fig. I.

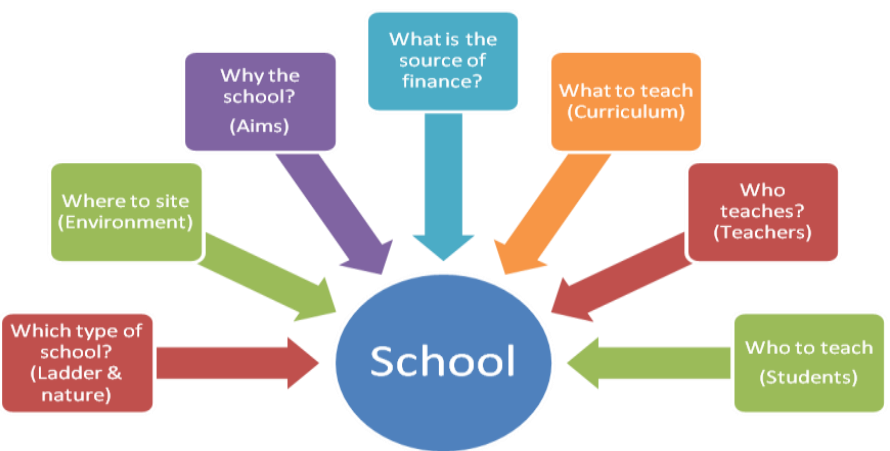

Fig. 1: The Ws for intending school Proprietors

${ }^{12}$ Shehu Adamu, Manpower Planning and Administration (BHM 654) (Lagos: National Open University of Nigeria, 2008), 2.

13 Lokman Abdul Rasol and S. Arni Basir, "Quality Management Features by Conventional and Islamic Perspectives: An Analysis of Theory," International Journal of Business and Management Tomorrow, vol. 2, no. 4, (2012), 4. 
A proper consideration of the above questions will assist proprietors of Islamic schools to plan properly before embarking on the task. This will help in reducing uncertainty in the future and thus enables the organization to do the job better and more efficiently. Positive response to those questions will no doubt be a strong foundation for successful administration of a Muslim school. As such, the manager of an ideal Islamic school determines the objectives for the school, examines the environment and projects the course of action and maps out the strategies for achieving the set objectives. Muhammad Bello cited Cheema and Hussain, to have listed what should be the vision of an Islamic school. These include among others:

i. to stop our children from being influenced by Godless ideologies;

ii. to realize that Islam is a comprehensive religion and its teachings relevant to every aspect of life and every subject of the curriculum in the school;

iii. Islamic precepts should condition and direct extracurricular and informal educational activities (sometimes referred to as hidden curricular) in the school;

iv. the entire environment of the school is permeated with (by) the fragrance of Islamic moral value, manners and etiquettes and vibrates with "Allah and His Messenger said." 14

The above points indicate that the mission of an Islamic school is richer and more comprehensive than that of a secular school. It therefore needs to put all machineries in motion to achieve the mission in addition to other conventional ones. In addition, the manager of an Islamic school is expected to keep himself abreast of the

14 I. Muhammad Bello, "The Mission and Vision of Model Islamic Schools in Nigeria" (Workshop for Teachers of Model Islamic Schools in Maiduguri, IIIT Nigeria Office and AMIS Borno State, 11-12 December 2010, 3-6. 
national goal of education, as his school is expected to carry out these dual roles.

At the classroom level, a teacher as a manager plans his lesson, set out objectives and how to achieve them. He also procures the needed instructional materials, directs and guides actions in the class.

\section{b. Teaching}

Teaching no doubt is a noble profession. It is the major task of Allah after His work of creation. He singlehandedly taught Adam, the first man the nature of all things and so elevated him above the angelic status. In the same vein, a teacher is expected to see his profession as a sacred and highly rewarding profession. Indeed, it is the work of enlivening the dead soul and elevating an ignorant to the status of intelligentsia.

In spite of the noble nature of teaching as a profession, the school administrator needs to understand that teachers too are human beings who can develop lukewarm attitude to their teaching responsibility. As such, the school administrator is not only expected to sit in his office but to walk round the classes to see the teachers at work. In addition to these, he serves as model for other teachers if he himself teaches occasionally. The example of his own teaching in the presence of his staff will motivate them to work hard and through this, his staff and pupils will come under his direct influence.

Occasional teaching will equally familiarize him with his pupils and through this, healthy relationship can be developed. Bidmos likens the relationship between teacher and students to the relationship between an experienced elderly person in his late fifties and a nine year old boy who is immature and inept. ${ }^{15}$ The bottom line of all these

${ }^{15}$ M.A. Bidmos, A Manual for the Teacher of Islamic Studies (Lagos: University of Lagos Press, 2010), 16. 
functions is that an Islamic school administrator must, as a matter of fact, be a role model to his pupils. He should not be the one that will engage in secret love affairs with any of his female teachers, so that his male teachers will not do that to their female students.

\section{c. Organizing}

This involves organizing the personnel as well as the physical resources available in the school for teachinglearning process. He places each teacher in the class where he can do the most useful work. He tries to identify any special talent shown by members of his staff and makes judicious use of such.

In addition to this, the practice of assigning a teacher to a subject he does not specialize on may hamper effective management of schools. It is a practice in some schools to ask a teacher of Islamic Studies, for instance, to teach Social Studies and the teacher of Agricultural Science to teach Mathematics. In the same vein, a well organized Muslim school manager will not appoint a secondary school leaver to teach in his school as such a candidate lacks the teaching techniques to carry out the assignment. It should also be reiterated that the minimum teaching requirement in Nigeria now is the Nigeria Certificate in Education (NCE) which only qualifies its owner to teach at basics 1-9, and not at Senior Secondary level.

\section{d. Supervision}

For any meaningful result in our schools, the school manager must be alive to his supervisory duties of getting work done through people. Many teachers are no longer as dedicated and committed as in those days. Many join teaching as a stepping stone to other lucrative employments and therefore lack the skills, the dedication and the psychological orientation. The manager has to be aware of this and he should be aware that he receives the lion's share of the praise or blame for the success or 
failure of the school respectively. So, he ensures that such segment of the school organization is up to its responsibilities. He makes sure that the school rules and regulations are obeyed.

Through supervision of teachers should be of utmost priority for the school manager than any other materials. We therefore concur with Abdulkareem that a poor syllabus and inadequate teaching materials in the hand of a well and versatile teacher may still be used to achieve impressive results, while a well sophisticated and innovative instructional material used in a suitable environment may produce unsatisfactory result if handled by a lazy and ill-motivated teacher. ${ }^{16}$ Since no education system can rise above the quality of its teachers, the teachers need to be well supervised to achieve the desired educational objectives in the school.

Apart from thorough supervision of the teaching staff, he also supervises the following with the help of his trained and experienced assistants:

i. Examinations: He takes the pain of testing the whole school, studies carefully the questions set by his staff and amends where necessary. He needs to study the markings of his staff so that he knows where weaknesses occur. The remarks made by each teacher on each pupil need to be properly monitored to avoid abusive language that hurt the feeling of parents.

ii. He monitors the activities of the account clerks to avoid financial mismanagement. He ensures that the school financial transactions are well documented. This will help in checking cases of fraud, embezzlement and financial recklessness. He himself should avoid using school money for his personal purposes.

iii. Effective supervision of all statutory records like log book, school register, class register, school dairy, time

\footnotetext{
${ }^{16}$ A.Y. Abdulkareem, "The Teacher as Manager", Unilorin Pedagogue vol. V (1988), 58-64.
} 
book, cash book, school time table, visitors' book, inventory, school fees payment register, teachers record of work/diaries, movement book, etc. These records are memory bank in which information is deposited and kept for future retrieval and utilization. They also help in assisting the school management to analyze and determine the number of teachers and other resources needed in the school. They also help to determine the termly and yearly performance of progress of students and the school in general.

iv. Proper supervision of non-academic staff such as gardeners, security guards, drivers, messengers etc.

v. Materials in the school must be adequately managed. These include the physical environment like classrooms, playing ground, fields and other movable and immovable materials. The library and laboratory of the school should also be properly managed to ensure security of the materials.

\section{e. Motivation}

One of the tools of effective management of schools is motivation, which is defined by Oyedeji as "a process of arousing enthusiasm in individual so that he can perform his duties with pleasure and high interest in pursuance of the organization and his personal goals." ${ }^{\prime 17}$ It is regarded as "something innate within individual, a kind of energizer or driving force, a desire or an urge that causes the individual to perform" and as well, an external stimulation that causes individual to perform. ${ }^{18}$ Motivation means a factor of force within and outside the organism which initiates, directs and sustains behaviour towards a goal. It is an inner drive which prompts people to act in certain way. ${ }^{19}$

17 N.B. Oyedeji, Management in Education: Principles and Practice (Ilorin: Success Educational Services, 2012), 60.

${ }^{18}$ Ibid.

${ }^{19}$ M.A. Eleregbe, "Motivation and Teachers' Productivity in Nigerian Schools" Unilorin Pedagogue vol. V (1988), 27. 
An ideal manager of an ideal Islamic school must find ways of motivating his staff so that the task before him can be accomplished. A teacher should not be made to understand that his reward is in heaven alone, rather, he has to have a share of the reward right from this earth. As such, to push him to work effectively, such tangible incentives like bonus payment and promotion, and intangible things such as leadership morale, job security and job satisfaction should be made available for the teachers and other non-teaching staff of the school. In other words, the manager should ensure that the human needs are given priority attention in the scheme of motivating his staff and students. A psychologist, Abraham Maslow has developed a theory of motivation through his classification of human needs into five, namely:

i. Physiological need

ii. Safety need

iii. Social need

iv. Self-esteem need

v. Self-actualization need. ${ }^{20}$

The physiological need involves provision of adequate hostel accommodation for students, where the school is a boarding school. Where it is not, it can take the form of adequate education of the parents on how they should make home comfortable for the children so that they are not over-burdened with running errands and petty trading that will expose them to environmental and human hazards. For the teachers, better condition of service can enhance their planning to have better accommodation which can also enhance their better performance at work.

The safety need for the students can be in form of ensuring adequate security from anything injurious while

${ }^{20}$ A.M. Sadeq, "Islamic Ethics in Human Resource Management" in Development Issues in Islam, ed. A.M. Sadeq (Selangor: International Islamic University Malaysia, 2006), 546-548. 
in school. As such, dilapidated classrooms or building should be pulled down, the furniture in the classroom should be safe for them to use. The school compound should be properly fenced to avoid students sneaking out the compound. If it is a nursery primary school, teachers' assistants need be employed to take adequate care of the pupils.

In addition, the school management is expected to be conversant with those who enter the school compound, as well as to have adequate record of those who come to pick the pupils after the school hours. If it is a boarding school, night guards should be employed to protect the students from thieves and hoodlums. As part of the safety measure, it is expected that male hostel be distanced from that of the females, while the school should take cognizance of the evil inherent in too much close contact of matured female students with male teachers especially in secluded places. In essence, the Shari' ${ }^{-a}$ requirement on relationship between male and female should be strictly adhered to, while the school environment should not condone prohibited relationship between them.

The social need as a form of motivation can be facilitated through encouraging the students to belong to a number of social groups in the school. As such, it is expected that the school puts in place some socioacademic and religious organizations in the school system. Such include the Muslim Students' Society, the Nigeria Aids Group in Islam, the Junior Engineer and Technologist Society, Young Farmers Club, Readers' Club, and the Literary and Debating Society among others. In the same vein, the school should encourage active participation of staff in different professional bodies like Mathematical Association of Nigeria, Science Teachers Association and the Nigeria Association of Teachers of Arabic and Islamic Studies among others. 
The recognition of achievements in staff and students is a good means of meeting their respective esteem needs. Also, the self-actualization need could be met through identification of the ability of each person in the school system and assigning them with the nature of the work commensurate with their ability. A good way of doing this can be in form of appointing school prefects and spelling out the responsibilities attached to each of the offices.

\section{Conclusion}

An administrator in the school set-up is like a heart in the body through whose healthiness the whole body is healthy and through whose being diseased the whole body is diseased. As such, he has to make the school 'healthy' through his planning, organizing, leading, coordinating, directing, supervising, controlling, evaluating and reporting roles. He must realize that his institution is a system and that within that system there are sub-systems each of which must make a definite contribution to the accomplishment of the overall goals of the school through his proper coordination.

In other words, the school proprietor or coordinator of any ideal Islamic model school is a manager who oversees the general affairs of the school while he designates each of these functions to his capable staffs who are also co-managers. To his employees, he provides a safe and clean environment and ensures that he pays their wages adequately. He allows them to develop themselves and feel free to make suggestions, complains and criticism. To the students, he provides the best qualitative education through employment of capable and qualified hands to teach them, while the environment that is conducive for learning is equally provided. To the parents, he ensures that the trust reposed in him is not betrayed in any way.

In our own view, a Muslim school administrator needs to be abreast of what management is in the 
perspective of his religion. He adheres strictly to the Islamic principles of ethics in human resource management which according to Sadeq include brotherhood and benevolence (al-Ukhuwwah wal-Ihsān), trust and honesty (al-Amānah wal-Ikhlāss), cooperation (al-Ta'āwun), justice (al- `Adl) and fair compensation (al'Ujrah). ${ }^{21}$ The knowledge of this will further enhance his performance as an administrator, and will also ensure the smooth running of the school, without violating the teaching of his religion. In doing this, he does not see his management of school as a means of getting terrestrial reward alone, but also a means of attracting celestial reward.

\section{References}

Abdulkareem, A.Y. "The Teacher as Manager", Unilorin Pedagogue vol. V. (1988): 58-64.

Lokman Abdul Rasol \& S. Arni Basir, "Quality Management Features by Conventional and Islamic Perspectives: An Analysis of Theory," International Journal of Business and Management Tomorrow, vol. 2, no. 4, (2012).

Adamu, Shehu. Manpower Planning and Administration (BHM 654). Lagos: National Open University of Nigeria, 2008.

Adebayo, R.I. "Islamization of the Curriculum: An Agenda for the Private Islamic Nursery Schools in Nigeria," Muslim Education Quarterly vol. 22, no. 3, (2005).

Agabi, C.O. \& Ogah, J.I. "Education and Human Resource Planning in Nigeria: The Case of National Manpower Board (NMB)," International Journal of Scientific Research in Education vol. 3, no. 3 (2010): 152-165. Retrieved http://www.ijsre.com.

${ }^{21} \mathrm{Ibid}$. 
Al-Buraey, M.A. Management \& Administration in Islam. n.p, 1990.

Bidmos, M.A. A Manual for the Teacher of Islamic Studies. Lagos: University of Lagos Press, 2010.

Eleregbe, M.A. "Motivation and Teachers' Productivity in Nigerian Schools," Unilorin Pedagogue vol. V (1988).

Gbosi, A.N. Economic of Human Resources Development. Choba: Emiham Printing and Publishing Co., 2003.

Hussein, S.S. \& Ashraf, S.A. Crisis in Muslim Education. Jeddah: Hodder and Stoughton and King Abdul Aziz University, 1979.

Muhammad Bello, I. "The Mission and Vision of Model Islamic Schools in Nigeria." Workshop for Teachers of Model Islamic Schools in Maiduguri, IIIT Nigeria Office and AMIS Borno State, 11-12 December 2010.

Oyedeji, N.B. Management in Education: Principles and Practice. Ilorin: Success Educational Services, 2012.

Sadeq, A.M. "Islamic Ethics in Human Resource Management." In Development Issues in Islam, ed. A.M. Sadeq. Selangor: International Islamic University Malaysia, 2006.

The Custodian of the Two Holy Mosques King Fahd Complex for the Printing of the Holy Qur'an. The Holy Qur'an: English Translation of the Meanings and Commentary. Madinah: King Fahd Complex for the Printing of the Holy Qur'an, 1413H. 
Adebayo, "Islamizing the Management of Human Resources," Afkār 17 (2015):

$79-102$ 